\title{
Elevated Root-Zone Temperature Modulates Growth and Quality of Hydroponically Grown Carrots
}

\author{
Masaru Sakamoto*, Takahiro Suzuki \\ Department of Biological Science, Faculty of Biology Oriented Science and Technology, Kindai University, \\ Wakayama, Japan \\ Email: sakamoto@waka.kindai.ac.jp
}

Received 10 July 2015; accepted 3 August 2015; published 6 August 2015

Copyright (C) 2015 by authors and Scientific Research Publishing Inc.

This work is licensed under the Creative Commons Attribution International License (CC BY). http://creativecommons.org/licenses/by/4.0/

c) (i) Open Access

\begin{abstract}
Air and soil temperatures strongly influence the growth and quality of crops. However, in root vegetables, such as carrot, few experiments aimed at regulating growth and quality by manipulating root-zone temperature have been reported. We investigated the effect of root-zone temperatures $\left(20^{\circ} \mathrm{C}, 25^{\circ} \mathrm{C}, 29^{\circ} \mathrm{C}\right.$, and $\left.33^{\circ} \mathrm{C}\right)$ on carrot growth and components using a hydroponic system. High root-zone temperatures for 14 days reduced shoot and rootgrowth and water content. In contrast, total phenolic compounds and soluble-solid content increased in tap roots under high-temperature treatment. Root oxygen consumption was upregulated after 7 days under high-temperature treatment. These results suggest that high root-zone temperatures induce drought-like stress responses that modulate carrot biomass and components. High root-zone temperature treatments administered to hydroponically grown crops may be a valuable tool for improving and increasing the quality and value of crops.
\end{abstract}

\section{Keywords}

Carrot, Root-Zone Temperature, Hydroponics, Phenolic Compounds, Drought Stress

\section{Introduction}

Hydroponics is a method of growing plants in nutrient solutions without soil and is used for crop production in environmentally-controlled cultivation systems, such as plant factories. In Japan, leafy vegetables, such as lettuce, spinach, and basil, grown in plant factories are already in the market [1]. Crops produced in factories

${ }^{*}$ Corresponding author. 
usually incur more cost than those grown in the field and greenhouse because of electricity bills and the expense of equipment and labor. Thus, it is necessary to add value to these crops by enhancing crop quality.

To date, various environmental cultivation conditions have been reported to improve plant growth and components. In lettuce, light quality and quantity influence the production of plant phenolic compounds, such as anthocyanin [2]-[4]. Blue and ultraviolet (UV) lights have been shown to increase the production of anthocyanin, which was accompanied by the activation of anthocyanin biosynthetic genes in leaf lettuce [3]. Light intensity and nitrogen-free hydroponic solution treatments are also important factors in lowering nitrate concentrations in lettuce leaf blades and petioles before harvest [5]. In tomato, salt stress improves fruit quality by increasing sugars, organic acids, and amino acids [6]-[9].

Temperature stress is also known to affect the quantities of plant organic components, including secondary metabolites [10] [11]. Elevated temperatures have been shown to decrease photosynthesis and biomass and increase root secondary-metabolite concentrations in the herb Panax quinquefolius [12]. In red leaf lettuce, low temperature accelerates the production of anthocyanin and chlorophylls [13]. Sugar and ascorbic acid contents of strawberry fruits were increased when plants were grown at low temperature [14], whereas anthocyanin content of these fruits was decreased at high-temperature treatment [15]. Thus, proper regulation of plant growing temperature could enhance plant components associated with increased human health or preference, resulting in increased crop market value.

Carrots are one of the major root vegetables and are consumed worldwide. The edible root, known as the tap root, contains various secondary metabolites, such as carotenoids and phenolic compounds, which have healthpromoting properties [16]. Recently, several hydroponic systems for cultivating carrots with or without medium have been studied [17]-[20]. Using a deep flow technique (DFT) hydroponic system, oxygen dissolved in the nutrient solution has been shown to be indispensable for the proper growth of the tap root [18]. In rockwool block hydroponics, the holes in the growth medium are important for the growth of carrot roots [17]. In perlite medium, the diameter of the perlite and the concentration of the hydroponic solution are key factors achieving maximum yield and high quality of hydroponically grown carrots [20]. To date, these hydroponic methods for growing carrots have been developed experimentally for stable carrot production.

Because nutrient solution is frequently circulated in hydroponic systems, solution conditions, such as nutrient constituents and temperature, can be easily regulated. To add value to hydroponically grown carrots, we investigated the effect of nutrient solution temperature on carrot growth and quality using a DFT hydroponic system.

\section{Materials and Methods}

\subsection{Plant material and Growth Conditions}

Carrot seeds (Daucus carota L. cv Tokinashigosun, Takii, Co. Ltd., Japan) were pregerminated for 1 day at $20^{\circ} \mathrm{C}$ under $200 \mu \mathrm{mol} \cdot \mathrm{m}^{-2} \cdot \mathrm{s}^{-1}$ photosynthetic photon flux (PPF) for $16 \mathrm{~h}$ under fluorescent lamps (FLs; FL40SBR-A; NEC Co., Japan). Germinated seeds were sown in sponge cubes of $2 \times 2 \times 2 \mathrm{~cm}$ and grown at the same condition. At 10 days after sowing (DAS), seedlings were transferred to the DFT hydroponic system with continuous aeration. The nutrient solution was based on one quarter strength culture solution of A-type Otsuka House Solution (Otsuka AgriTechno Co. Ltd., Japan). To avoid the entangling of seedling roots, roots were untangled every 3 days. At 30 DAS, plants for which one main root was sufficiently elongated with an active root tip were transferred to a new DFT system with a 25-cm-deep box. Plants were cultivated at $20^{\circ} \mathrm{C}$ under 250 $\mu \mathrm{mol} \cdot \mathrm{m}^{-2} \cdot \mathrm{s}^{-1} \mathrm{PPF}$ for $16 \mathrm{~h}$ under FLs. Root-zone temperature $\left(25^{\circ} \mathrm{C}, 29^{\circ} \mathrm{C}\right.$, and $\left.33^{\circ} \mathrm{C}\right)$ was controlled by heating the nutrient solution using an IC auto heater (DS 150; DEX Co., Japan). The root-zone treatment at $20^{\circ} \mathrm{C}$ was not controlled because this temperature was the ambient temperature. To avoid the entangling of seedling roots, roots were untangled every 3 days. Growth parameters of leaf number, shoot length, and tap root diameter were measured at $1-4,6-11,13$, and14 DAS. At 44 DAS, plants were harvested and growth parameters and components were analyzed.

\subsection{Measurement of Total Phenol Content}

Total phenol content was measured using the modified Folin-Ciocalteu method [21]. Sliced tap root segments (50 mg) were homogenized with $500 \mu \mathrm{L}$ of $90 \%$ methanol and stored at $4^{\circ} \mathrm{C}$ overnight. The sample was then centrifuged at $10,000 \times g$ for $5 \mathrm{~min}$. The supernatant $(50 \mu \mathrm{L})$ was diluted with distilled water to $650 \mu \mathrm{L}$, and 50 
$\mu \mathrm{L}$ phenol reagent was mixed with it. After addition of $300 \mu \mathrm{L}$ of $5 \%$ sodium carbonate, the mixture was incubated at $25^{\circ} \mathrm{C}$ for $30 \mathrm{~min}$. The absorbance of the supernatant was measured at $765 \mathrm{~nm}$, and a standard curve was prepared using gallic acid. The absorbance was converted to total phenol content in terms of milligrams of gallic acid equivalent per gram of fresh weight of sample.

\subsection{Measurement of Anthocyanin Content}

Anthocyanin content was measured spectrophotometrically as previously described [21] with slight modification. Sliced tap root segments (50 mg) were homogenized with $500 \mu \mathrm{L}$ methanol and $1 \%$ hydrochloric acid and stored at $4^{\circ} \mathrm{C}$ overnight. The sample was then centrifuged at $10,000 \times g$ for $5 \mathrm{~min}$. The absorbance of the supernatant was measured at $533 \mathrm{~nm}$, and a standard curve was prepared using cyanidin-3-glucoside. The absorbance was converted to anthocyanin content in terms of milligrams of cyanidin-3-glucoside equivalent per gram fresh weight of sample.

\subsection{Measurement of Carotene Contents}

Sliced tap root segments $\left(20 \mathrm{mg}\right.$ ) were homogenized with $1 \mathrm{~mL}$ acetone and stored at $4^{\circ} \mathrm{C}$ overnight. The sample was then centrifuged at $10,000 \times g$ for $5 \mathrm{~min}$. The absorbance of the supernatant was measured at 443,475 , and $492 \mathrm{~nm}$, and total carotenoid, $\alpha$-carotene, and $\beta$-carotene concentrations were calculated as previously described [22].

\subsection{Measurement of Soluble Solid Content}

Sliced tap root segments were homogenized with a pestle and mortar, and the homogenates were filtered with filter paper (No. 1, Whatman plc., UK) to remove tissue debris. The concentration of soluble solids was measured using an Atago PAL-1 Handheld Digital Brix Refractometer (Atago, Japan).

\subsection{Measurement of Root Activity}

Root respiration rate was measured at 7 and 14 days post-treatment. Root segments $(50 \mathrm{mg}$ ) were immersed in oxygen-saturated nutrient solution in a 50-mL tube for $1 \mathrm{~h}$. The initial and final dissolved oxygen concentrations were measured with a DO-5509 dissolved oxygen meter (Lutron, Taiwan) for calculation of dissolved oxygen depletion.

\subsection{Measurement of Chlorophyll Content}

Chlorophyll content was measured spectrophotometrically as previously described [23] with slight modification. Leaf segments (50 mg) were homogenized with $500 \mu \mathrm{L}$ of $80 \%$ acetone and stored at $4{ }^{\circ} \mathrm{C}$ overnight. The sample was then centrifuged at $10,000 \times g$ for 5 min and the absorbance of the supernatant was measured at $652 \mathrm{~nm}$.

\subsection{Data Analysis}

The data obtained for each parameter were analyzed with the statistical package JMP (SAS Institute, Cary, NC, USA). Differences among treatments were determined by one-way analysis of variance (ANOVA). Mean comparisons were made using the Tukey-Kramer honestly significant difference multiple range test at $p<0.05$.

\section{Results}

Fourteen-day treatments at various root-zone temperatures influenced the growth of hydroponically grown carrots (Figure 1, Figure 2, and Table 1). Root-zone heating at $33^{\circ} \mathrm{C}$ significantly reduced leaf number, shoot length, and tap root diameter after 14 days (Figure 1). Time-course observation revealed that growth suppression of aboveground parts of the pants (as leaf number and shoot length) was induced over 10 days of treatment, whereas suppression of tap root diameter was induced within 9 days (Figure 1). Thus, elevated root-zone temperatures primarily influenced tap root growth and then shoot growth. After 14 days of treatment, shoot size of plants heated at $33^{\circ} \mathrm{C}$ was less than that of plants receiving lower temperature treatments, and this was also accompanied by leaf de-greening (Figure 2). In accordance with this observation, leaf chlorophyll content was 

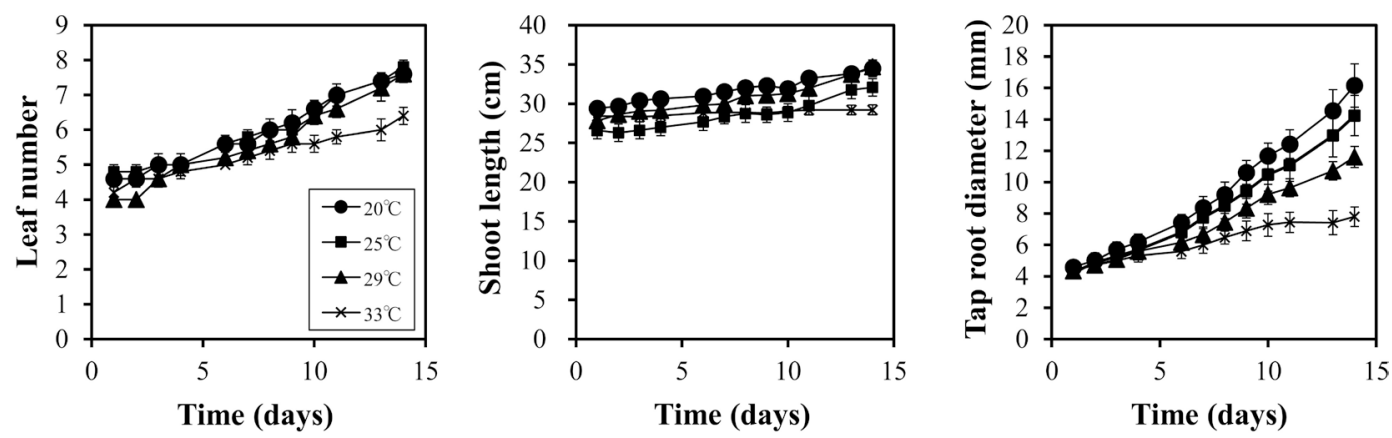

Figure 1. Time-course changes in leaf number, shoot length, and tap-root diameter of carrots grown at four different root-zone temperatures. Vertical bars represent \pm SE $(n=5)$.

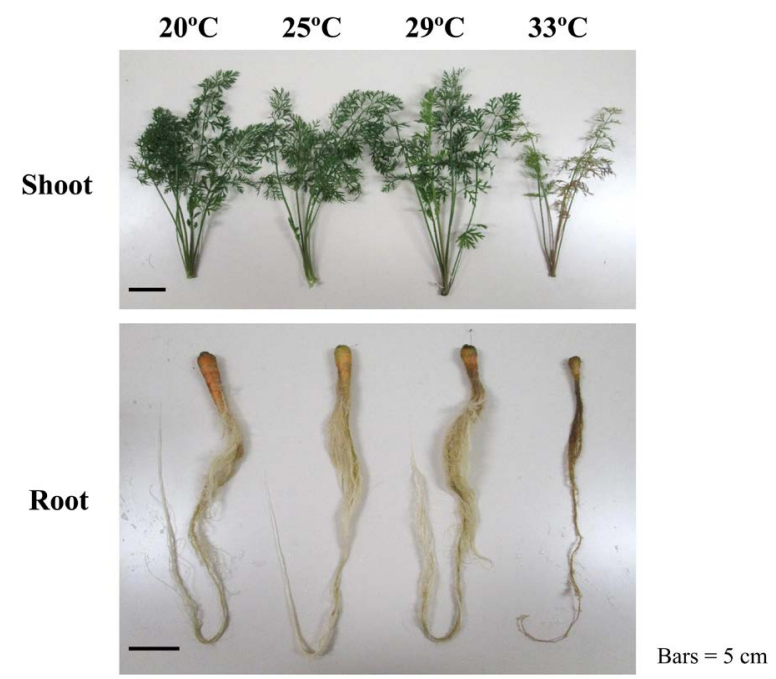

Figure 2. Shoots and roots of carrots grown at four different root-zone temperatures.

Table 1. Growth parameters of carrots grown at four different root-zone temperatures.

\begin{tabular}{ccccc}
\hline Root zone temp. & Leaf number & Shoot length $(\mathbf{c m})$ & Total root length $(\mathbf{c m})$ & Tap root diameter (mm) \\
\hline $\mathbf{2 0}^{\circ} \mathbf{C}$ & $7.6 \pm 0.2 \mathrm{a}$ & $34.5 \pm 1.1 \mathrm{a}$ & $61.7 \pm 6.3 \mathrm{a}$ & $16.8 \pm 1.5 \mathrm{a}$ \\
$\mathbf{2 5}^{\circ} \mathbf{C}$ & $7.8 \pm 0.2 \mathrm{a}$ & $32.1 \pm 1.1 \mathrm{ab}$ & $65.2 \pm 3.4 \mathrm{a}$ & $14.2 \pm 1.3 \mathrm{ab}$ \\
$\mathbf{2 9}^{\circ} \mathbf{C}$ & $7.6 \pm 0.2 \mathrm{a}$ & $34.7 \pm 0.9 \mathrm{a}$ & $67.4 \pm 4.2 \mathrm{a}$ & $11.6 \pm 0.7 \mathrm{bc}$ \\
$\mathbf{3 3}^{\circ} \mathbf{C}$ & $6.4 \pm 0.2 \mathrm{~b}$ & $29.2 \pm 0.6 \mathrm{~b}$ & $42.1 \pm 2.3 \mathrm{~b}$ & $7.8 \pm 0.6 \mathrm{c}$ \\
\hline
\end{tabular}

Values are mean \pm SE $(n=5)$. Different letters in the same column indicate significant differences by Tukey-Kramer honesty significant difference test $(p<0.05)$.

reduced by $33^{\circ} \mathrm{C}$ root-zone temperature treatment (Figure 3). Root length and tap-root diameter of plants heated at $33^{\circ} \mathrm{C}$ were also smaller than those of the plants grown at lower temperatures, and this was accompanied with fibrous root browning (Figure 2 and Table 1). The fresh weights of shoots and fibrous roots were decreased at $33^{\circ} \mathrm{C}$, whereas tap-root fresh weight was more strongly influenced by temperatures below $33^{\circ} \mathrm{C}$ (Table 2), results also observed for dry weight and relative growth rate (RGR) (Table 2 and Table 3). Water content of shoots and roots was decreased at $33^{\circ} \mathrm{C}$ (Table 2) suggesting the acceleration of shoot transpiration and/or the inhibition of root water-uptake by high root-zone temperature treatment. The ratios of the shoot/tap-root and shoot/fibrous root were increased between $20^{\circ} \mathrm{C}$ to $29^{\circ} \mathrm{C}$ in a temperature-dependent manner (Table 3). This result may explain the different temperature sensitivities of shoots and roots. The total phenol content of the taproot was increased in a temperature-dependent manner (Figure 4), whereas there were no significant differences 


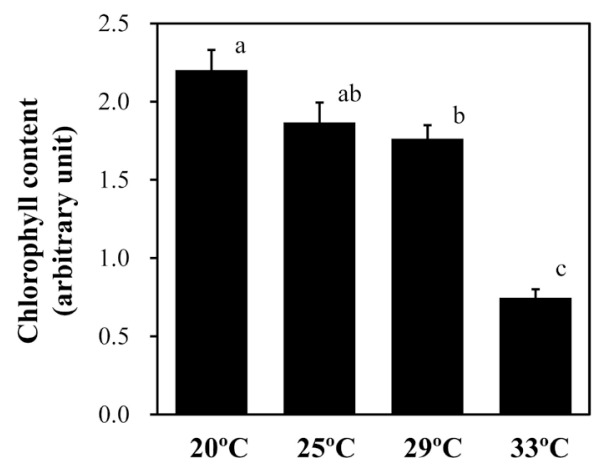

Figure 3. Effect of root-zone temperatures on chlorophyll content of carrot leaves. Vertical bars represent $\pm \operatorname{SE}(n=5)$. Different letters indicate significant difference by Tukey-Kramer honesty significant difference test $(p<0.05)$.

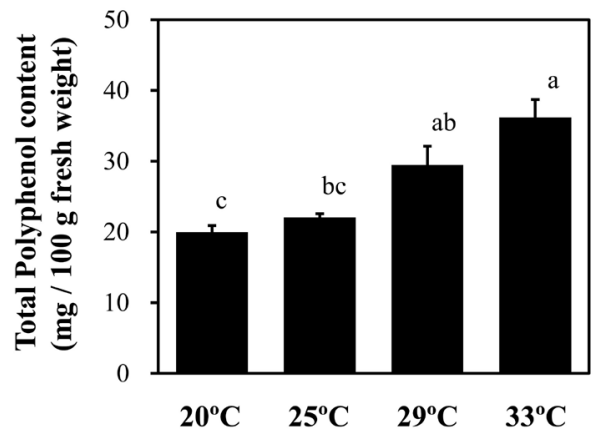

Figure 4. Effect of root-zone temperatures on total phenol content of carrot tap roots. Vertical bars represent \pm SE $(n=5)$. Different letters indicate significant difference by Tukey-Kramer honesty significant difference test $(p<0.05)$.

Table 2. Fresh weight, dry weight, and water content of carrots grown at four different root-zone temperatures.

\begin{tabular}{|c|c|c|c|c|c|c|c|c|c|}
\hline \multirow{2}{*}{$\begin{array}{l}\text { Root } \\
\text { zone } \\
\text { temp. }\end{array}$} & \multicolumn{3}{|c|}{ Fresh weight (g) } & \multicolumn{3}{|c|}{ Dry weight (g) } & \multicolumn{3}{|c|}{ Water content (\%) } \\
\hline & Shoot & Tap root & Fibrous root & Shoot & Tap root & Fibrous root & Shoot & Tap root & Fibrous root \\
\hline $20^{\circ} \mathrm{C}$ & $10.4 \pm 1.6 \mathrm{a}$ & $13.5 \pm 1.7 \mathrm{a}$ & $7.1 \pm 1.5 \mathrm{a}$ & $1.70 \pm 0.24 \mathrm{a}$ & $1.56 \pm 0.2 \mathrm{a}$ & $0.36 \pm 0.07 \mathrm{ab}$ & $83.5 \pm 0.4 \mathrm{a}$ & $88.6 \pm 0.2 \mathrm{a}$ & $94.8 \pm 0.1 \mathrm{a}$ \\
\hline $25^{\circ} \mathrm{C}$ & $10.3 \pm 0.6 \mathrm{a}$ & $10.2 \pm 1.1 \mathrm{ab}$ & $8.3 \pm 0.9 \mathrm{a}$ & $1.70 \pm 0.13 \mathrm{a}$ & $1.18 \pm 0.1 \mathrm{ab}$ & $0.43 \pm 0.05 \mathrm{a}$ & $83.7 \pm 0.3 \mathrm{a}$ & $88.4 \pm 0.4 \mathrm{a}$ & $94.8 \pm 0.1 \mathrm{a}$ \\
\hline $29^{\circ} \mathrm{C}$ & $11.2 \pm 1.3 \mathrm{a}$ & $7.4 \pm 0.7 \mathrm{bc}$ & $7.9 \pm 0.8 \mathrm{a}$ & $1.88 \pm 0.19 \mathrm{a}$ & $0.92 \pm 0.1 \mathrm{~b}$ & $0.45 \pm 0.04 \mathrm{a}$ & $83.1 \pm 0.4 \mathrm{a}$ & $87.5 \pm 0.2 \mathrm{a}$ & $94.3 \pm 0.3 \mathrm{a}$ \\
\hline $33^{\circ} \mathrm{C}$ & $3.8 \pm 0.3 b$ & $3.7 \pm 0.5 \mathrm{c}$ & $1.4 \pm 0.2 \mathrm{~b}$ & $0.84 \pm 0.04 \mathrm{~b}$ & $0.64 \pm 0.1 \mathrm{~b}$ & $0.18 \pm 0.03 \mathrm{~b}$ & $77.4 \pm 0.9 \mathrm{~b}$ & $82.5 \pm 0.7 b$ & $87.3 \pm 0.4 b$ \\
\hline
\end{tabular}

Values are mean \pm SE $(n=5)$. Different letters in the same column indicate significant differences by Tukey-Kramer honesty significant difference test $(p<0.05)$.

Table 3. Relative growth rate (RGR) and organ ratio of carrots grown at four different root-zone temperatures.

\begin{tabular}{|c|c|c|c|c|c|c|}
\hline \multirow{2}{*}{$\begin{array}{l}\text { Root zone } \\
\text { temp. }\end{array}$} & \multicolumn{3}{|c|}{ RGR $\left(g^{\prime} \cdot g^{-1} \cdot\right.$ day $\left.^{-1}\right)$} & \multicolumn{3}{|c|}{ Ratio of plant organ } \\
\hline & Shoot & Tap root & Fibrous root & Shoot/Tap root & Shoot/Fibrous root & Tap root/Fibrous root \\
\hline $20^{\circ} \mathrm{C}$ & $0.134 \pm 0.011 \mathrm{a}$ & $0.218 \pm 0.011 \mathrm{a}$ & $0.108 \pm 0.014 \mathrm{a}$ & $0.90 \pm 0.08 \mathrm{~b}$ & $1.12 \pm 0.12 \mathrm{~b}$ & $0.24 \pm 0.04 \mathrm{~b}$ \\
\hline $25^{\circ} \mathrm{C}$ & $0.136 \pm 0.005 \mathrm{a}$ & $0.200 \pm 0.008 \mathrm{ab}$ & $0.124 \pm 0.008 \mathrm{a}$ & $1.07 \pm 0.08 \mathrm{ab}$ & $1.50 \pm 0.17 \mathrm{ab}$ & $0.39 \pm 0.06 \mathrm{ab}$ \\
\hline $29^{\circ} \mathrm{C}$ & $0.142 \pm 0.008 \mathrm{a}$ & $0.183 \pm 0.006 \mathrm{bc}$ & $0.128 \pm 0.007 \mathrm{a}$ & $1.39 \pm 0.15 \mathrm{a}$ & $2.09 \pm 0.26 \mathrm{a}$ & $0.49 \pm 0.03 \mathrm{a}$ \\
\hline $33^{\circ} \mathrm{C}$ & $0.087 \pm 0.003 b$ & $0.156 \pm 0.009 \mathrm{c}$ & $0.059 \pm 0.010 \mathrm{~b}$ & $1.07 \pm 0.09 a b$ & $1.40 \pm 0.15 \mathrm{ab}$ & $0.29 \pm 0.06 b$ \\
\hline
\end{tabular}

Values are mean \pm SE $(n=5)$. Different letters in the same column indicate significant differences by Tukey-Kramer honesty significant difference test $(p<0.05)$. 
between the different temperature treatment groups in total carotenoids, carotenes, and anthocyanin (Table 4). Tap-root soluble-solid content expressed by Brix was higher at $29^{\circ} \mathrm{C}$ than at lower temperatures and was further increased at $33^{\circ} \mathrm{C}$ (Figure 5), suggesting an increase of sugar content with root-zone temperature rise. Root activity measured by oxygen consumption at 7 and 14 days of treatment increased with root-zone temperature (Figure 6).

Table 4. Carotenes and anthocyanin contents of carrots grown at four different root zone temperatures.

\begin{tabular}{ccccc}
\hline $\begin{array}{c}\text { Root zone } \\
\text { temp. }\end{array}$ & $\begin{array}{c}\text { Total carotenoid } \\
(\boldsymbol{\mu g} / \mathbf{g} \text { fresh weight) }\end{array}$ & $\begin{array}{c}\boldsymbol{\alpha} \text {-carotene } \\
(\boldsymbol{\mu g} / \mathbf{g} \text { fresh weight })\end{array}$ & $\begin{array}{c}\boldsymbol{\beta} \text {-carotene } \\
(\boldsymbol{\mu g} / \mathbf{g} \text { fresh weight) }\end{array}$ & $\begin{array}{c}\text { Anthocyanin } \\
(\boldsymbol{\mu g} / \mathbf{g} \text { fresh weight) }\end{array}$ \\
\hline $\mathbf{2 0 ^ { \circ } \mathbf { C }}$ & $161.5 \pm 15.9 \mathrm{a}$ & $103.0 \pm 10.4 \mathrm{a}$ & $39.3 \pm 2.5 \mathrm{a}$ & $103.5 \pm 9.0 \mathrm{a}$ \\
$\mathbf{2 5 ^ { \circ } \mathbf { C }}$ & $137.1 \pm 15.9 \mathrm{a}$ & $88.1 \pm 9.9 \mathrm{a}$ & $34.7 \pm 2.9 \mathrm{a}$ & $129.3 \pm 9.0 \mathrm{a}$ \\
$\mathbf{2 9}^{\circ} \mathbf{C}$ & $131.2 \pm 12.1 \mathrm{a}$ & $86.7 \pm 7.7 \mathrm{a}$ & $30.7 \pm 2.0 \mathrm{a}$ & $134.0 \pm 14.6 \mathrm{a}$ \\
$\mathbf{3 3}^{\circ} \mathbf{C}$ & $140.5 \pm 24.0 \mathrm{a}$ & $93.1 \pm 15.0 \mathrm{a}$ & $31.6 \pm 4.0 \mathrm{a}$ & $136.4 \pm 22.8 \mathrm{a}$ \\
\hline
\end{tabular}

Values are mean \pm SE $(n=5)$. Different letters in the same column indicate significant differences by Tukey-Kramer honesty significant difference test $(p<0.05)$.

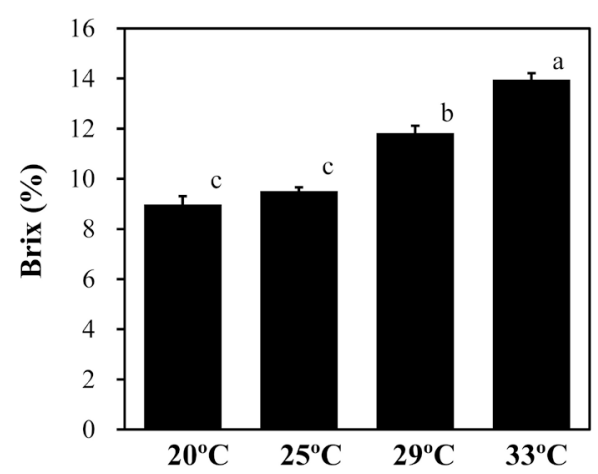

Figure 5. Effect of root-zone temperatures on soluble solid content of tap roots. Vertical bars represent \pm SE $(n=5)$. Different letters indicate significant difference by Tukey-Kramer honesty significant difference test $(p<0.05)$.

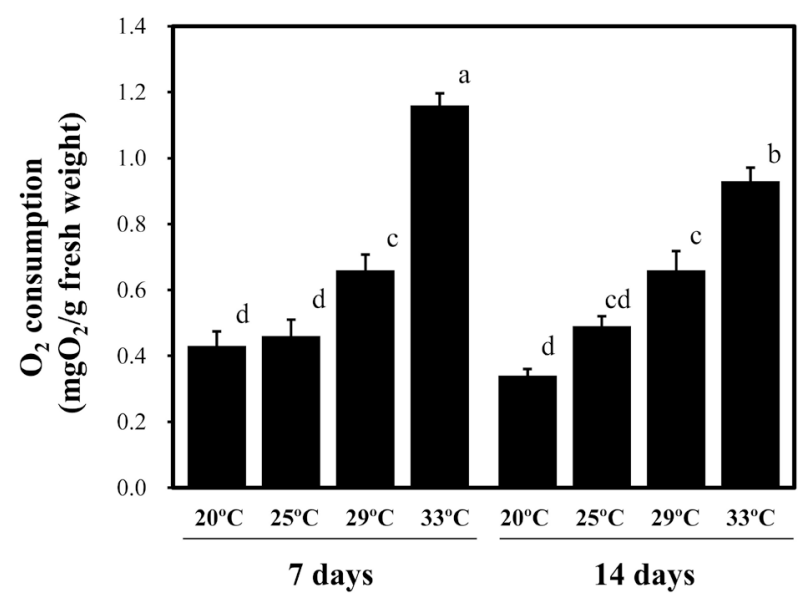

Figure 6. Effect of root-zone temperatures on respiration of fibrous roots. Vertical bars represent \pm SE $(n=4)$. Different letters indicate significant difference by Tukey-Kramer honesty significant difference test $(p<0.05)$. 


\section{Discussion}

Similar to other plants, carrots accumulate various secondary metabolites in response to temperature [24]-[26]. Higher temperatures led to higher accumulations of terpenoid volatiles in carrots in a controlled climate chamber experiment [25]. In carrot suspension cell cultures, incubation of cells at $30^{\circ} \mathrm{C}$ increased production of anthocyanin from that at $20^{\circ} \mathrm{C}$ and $25^{\circ} \mathrm{C}$ [26]. In agreement with these findings, we observed that high root-zone temperature increased the production of phenolic compounds (Figure 4). In contrast, the contents of carotenes and anthocyanin were not influenced by root-zone temperature (Table 4), indicating the presence of diverse temperature responses in carrot secondary metabolism. Interestingly, carrot total biomass increased by $37 \%$ with a $1^{\circ} \mathrm{C}$ rise in soil temperature in a field experiment [24]. In contrast, we observed that high root-zone temperature suppressed the growth of shoot and root biomass (Table 2). This difference is probably due to the low temperatures $\left(7.5^{\circ} \mathrm{C}-10.9^{\circ} \mathrm{C}\right)$ used in the field experiment differing from optimum temperatures and our experimental conditions $\left(20^{\circ} \mathrm{C}-33^{\circ} \mathrm{C}\right)[24]$. Different cultivation methods and cultivars may also have accounted for this contrary result.

Although poorly studied in carrots, root-zone temperature is an important factor for the production of various plant metabolites in many plants [27]-[29]. In African snake tomato (Trichosanthes cucumerina L.), amounts of phenolics, ascorbic acid, and chlorophylls increased with increasing root-zone temperature [27]. In contrast, cucumber seedlings exposed to low root-temperature $\left(12^{\circ} \mathrm{C}\right)$ had significantly higher soluble sugar content than those at $20^{\circ} \mathrm{C}$ [28]. Raising or lowering root-zone temperature altered the synthesis and accumulation of several alkaloids differently in Catharanthus roseus and Nicotiana tabacum [29]. Interestingly, the changes in alkaloid accumulation were observed within 2 days of treatment [29]. In our study, high-temperature treatment of the root zone for 14 days increased the production of phenolic compounds and soluble solid contents, but also led to suppression of growth in hydroponically grown carrots (Figure 1, Figure 2, Table 1, and Table 2). Thus, shortterm treatment with high root-zone temperature in hydroponically grown carrots may increase growth while preserving the accumulation of secondary metabolites.

Drought and salt stress to the root was shown to lead to plant growth suppression followed by leaf photosynthetic impairment [30]. High temperature also promoted a decline in photosynthesis and shoot and grain mass and reduced water-use efficiency, responses resembling drought stress responses [31]. Similarly, we observed drought stress-like reduction of shoot and root water content under high root-zone temperature treatments (Table 2). Temperature stress to the root zone reduced photosynthetic capacity [32] [33]. In rice seedlings, high root-zone temperatures compared with shoot temperature accelerated leaf chilling injury, and this was preceded by the photoinhibition of photosystem II [32]. In our study, high root-zone temperature caused photo-oxidative damage, as represented by the loss of leaf chlorophyll (Figure 3), suggesting that root temperature stress first indirectly represses leaf photosynthesis, resulting in shoot growth inhibition. Elevation of root oxygen consumption by high root-zone temperature treatment (Figure 6) may also be a drought stress-like response. Indeed, water deficit in the rhizosphere leads to an increased rate of root respiration followed by a reduction in plant growth [34].

\section{Conclusion}

Environmental stresses influence plant metabolism, including changes of plant components [6]-[15] [24]-[29]. To increase crop components associated with human health or preferences such as phenolic compounds and sugars, stress treatments have previously been applied during the cultivation periods in several crops including tomato [35]. In the present study, we showed that high root-zone temperature treatments of nutrient solutions increased phenolic compounds and soluble solid content in hydroponically-grown carrot tap roots. Although there appears to be a tradeoff between growth rate and production of several plant metabolites, our findings propose a useful technique for improving the quality of crops, including root vegetables.

\section{References}

[1] Kozai, T. (2012) Plant Factory with Artificial Light. Ohmsha Ltd., Tokyo.

[2] Park, J.S., Choung, M.G., Kim, J.B., Hahn, B.S., Kim, J.B., Bae, S.C., Roh, K.H., Kim, Y.H., Cheon, C.I., Sung, M.K. and Cho, K.J. (2007) Genes Up-Regulated during Red Coloration in UV-B Irradiated Lettuce Leaves. Plant Cell Reports, 26, 507-516. http://dx.doi.org/10.1007/s00299-006-0255-X 
[3] Johkan, M., Shoji, K., Goto, F., Hhida, S. and Yoshihara, T. (2011) Effect of Green Light Wavelength and Intensity on Photomorphogenesis and Photosynthesis in Lactuca sativa. Environmental and Experimental Botany, 75, 128-133. http://dx.doi.org/10.1016/j.envexpbot.2011.08.010

[4] Kazan, K. and Manners, J.M. (2011) The Interplay between Light and Jasmonate Signalling during Defence and Development. Journal of Experimental Botany, 62, 4087-4100. http://dx.doi.org/10.1093/jxb/err142

[5] Liu, W.K. and Yang, Q.C. (2011) Effects of Short-Term Treatment with Various Light Intensities and Hydroponic Solutions on Nitrate Concentration of Lettuce. Acta Agriculturae Scandinavica Section B-Soil \& Plant Science, 62, 109113.

[6] Tal, M., Katz, A., Heikin, H. and Dehan, K. (1979) Salt Tolerance in the Wild Relatives of the Cultivated Tomato: Proline Accumulation in Lycopersicon esculentum Mill., L. peruvianum Mill. and Solanum pennellii Cor. Treated with $\mathrm{NaCl}$ and Polyethyleneglycol. New Phytologist, 82, 349-355. http://dx.doi.org/10.1111/j.1469-8137.1979.tb02660.x

[7] Adams, P. (1991) Effects of Increasing the Salinity of the Nutrient Solution with Major Nutrients or Sodium Chloride on the Yield, Quality and Composition of Tomatoes Grown in Rockwool. Journal of Horticultural Science, 66, 201207.

[8] Gao, Z., Sagi, M. and Lips, S.H. (1998) Carbohydrate Metabolism in Leaves and Assimilate Partitioning in Fruits of Tomato (Lycopersicon esculentum L.) as Affected by Salinity. Plant Science, 135, 149-159. http://dx.doi.org/10.1016/S0168-9452(98)00085-5

[9] Saito, T., Matsukura, C., Ban, Y., Shoji, K., Sugiyama, M., Fukuda, N. and Nishimura, S. (2008) Salinity Stress Affects Assimilate Metabolism at the Gene-Expression Level during Fruit Development and Improves Fruit Quality in Tomato (Solanum lycopersicum L.). Journal of the Japanese Society for Horticultural Science, 77, 61-68. http://dx.doi.org/10.2503/jjshs1.77.61

[10] Kaplan, F., Kopka, J., Haskell, D.W., Zhao, W., Schiller, K.C., Gatzke, N., Sung, D.Y. and Guy, C.L. (2004) Exploring the Temperature-Stress Metabolome of Arabidopsis. Plant Physiology, 136, 4159-4168. http://dx.doi.org/10.1104/pp.104.052142

[11] Ramakrishna, A. and Ravishankar, G.A. (2011) Influence of Abiotic Stress Signals on Secondary Metabolites in Plants. Plant Signaling \& Behavior, 6, 1720-1731. http://dx.doi.org/10.4161/psb.6.11.17613

[12] Jochum, G.M., Mudge, K.W. and Thomas, R.B. (2007) Elevated Temperatures Increase Leaf Senescence and Root Secondary Metabolite Concentration in the Understory Herb Panax quinquefolius (Araliaceae). American Journal of Botany, 94, 819-826. http://dx.doi.org/10.3732/ajb.94.5.819

[13] Gazula, A., Kleinhenz, M.D., Streeter, J.G. and Miller, A.R. (2005) Temperature and Cultivar Effects on Anthocyanin and Chlorophyll b Concentrations in Three Related Lollo Rosso Lettuce Cultivars. HortScience, 40, 1731-1733.

[14] Wang, S.Y. and Camp, M.J. (2000) Temperatures after Bloom Affect Plant Growth and Fruit Quality of Strawberry. Scientia Horticulturae, 85, 183-199. http://dx.doi.org/10.1016/S0304-4238(99)00143-0

[15] Ikeda, T., Suzuki, N., Nakayama, M. and Kawakami, Y. (2011) The Effects of High Temperature and Water Stress on Fruit Growth and Anthocyanin Content of Pot-Grown Strawberry (Fragaria×ananassa Duch. cv. "Sachinoka”) Plants. Environment Control in Biology, 49, 209-215. http://dx.doi.org/10.2525/ecb.49.209

[16] Bozalana, N.K. and Karadeniza, F. (2011) Carotenoid Profile, Total Phenolic Content, and Antioxidant Activity of Carrots. International Journal of Food Properties, 14, 1060-1068. http://dx.doi.org/10.1080/10942910903580918

[17] Islam, A.F.M.S., Hirai, H. and Kitaya, Y. (2008) Hydroponic Cultivation of Carrots Using Modified Rockwool Blocks. Journal of Applied Horticulture, 10, 132-136.

[18] Terabayashi, S., Harada, N., Date, S. and Fujime, Y. (2008) Effects of Aeration and Root Immersion Level on the Development of Carrot Root in Hydroponics. Horticultural Research (Japanese), 7, 439-444. http://dx.doi.org/10.2503/hrj.7.439

[19] Gichuhi, P.N., Mortley, D., Bromfield, E. and Bovell-Benjamin, A.C. (2009) Nutritional, Physical, and Sensory Evaluation of Hydroponic Carrots (Daucus carota L.) from Different Nutrient Delivery Systems. Journal of Food Science, 74, S403-S412. http://dx.doi.org/10.1111/j.1750-3841.2009.01338.x

[20] Asaduzzaman, M., Kobayashi, Y., Mondal, M.F., Ban, T., Matsubara, H., Adachi, F. and Asao, T. (2013) Growing Carrots Hydroponically Using Perlite Substrates. Scientia Horticulturae, 159, 113-121. http://dx.doi.org/10.1016/j.scienta.2013.04.038

[21] Leja, M., Kaminska, I., Kramer, M., Maksylewicz-Kaul, A., Kammerer, D., Carle, R. and Baranski, R. (2013) The Content of Phenolic Compounds and Radical Scavenging Activity Varies with Carrot Origin and Root Color. Plant Foods for Human Nutrition, 68, 163-170. http://dx.doi.org/10.1007/s11130-013-0351-3

[22] Nagata, M., Noguchi, Y., Sugiyama, K. and Imanishi, S. (2006) A Simple Method for the Estimation of Alpha- and Beta-Carotene in Carrots. Acta Horticulturae, 8, 565-569. 
[23] Sakamoto, M., Munemura, I., Tomita, R. and Kobayashi, K. (2008) Involvement of Hydrogen Peroxide in Leaf Abscission Signaling, Revealed by Analysis with an in Vitro Abscission System in Capsicum Plants. The Plant Journal, 56, 13-27. http://dx.doi.org/10.1111/j.1365-313X.2008.03577.x

[24] Wheeler, T.R., Morison, J.I.L., Ellis, R.H. and Hadley, P. (1994) The Effects of $\mathrm{CO}_{2}$, Temperature and Their Interaction on the Growth and Yield of Carrot (Daucus carota L.). Plant, Cell \& Environment, 17, 1275-1284. http://dx.doi.org/10.1111/j.1365-3040.1994.tb00529.x

[25] Rosenfeld, H.J., Aaby, K. and Lea, P. (2002) Influence of Temperature and Plant Density on Sensory Quality and Volatile Terpenoids of Carrot (Daucus carota L.) Root. Journal of the Science of Food and Agriculture, 82, 1384-1390. http://dx.doi.org/10.1002/jsfa.1200

[26] Narayan, M.S., Thimmaraju, R. and Bhagyalakshmi, N. (2004) Interplay of Growth Regulators during Solid-State and Liquid-State Batch Cultivation of Anthocyanin Producing Cell Line of Daucus carota. Process Biochemistry, 40, 351358. http://dx.doi.org/10.1016/j.procbio.2004.01.009

[27] Adebooye, O.C., Schmitz-Eiberger, M., Lankes, C. and Noga, G.J. (2010) Inhibitory Effects of Sub-Optimal Root Zone Temperature on Leaf Bioactive Components, Photosystem II (PS II) and Minerals Uptake in Trichosanthes cucumerina L. Cucurbitaceae. Acta Physiologiae Plantarum, 32, 67-73. http://dx.doi.org/10.1007/s11738-009-0379-Z

[28] Yan, Q., Duan, Z., Mao, J., Xun, L. and Fei, D. (2013) Low Root Zone Temperature Limits Nutrient Effects on Cucumber Seedling Growth and Induces Adversity Physiological Response. Journal of Integrative Agriculture, 12, 14501460. http://dx.doi.org/10.1016/S2095-3119(13)60549-3

[29] Malik, S., Andrade, S.A.L., Sawaya, A.C.H.F., Bottcher, A. and Mazzafera, P. (2013) Root-Zone Temperature Alters Alkaloid Synthesis and Accumulation in Catharanthus roseus and Nicotiana tabacum. Industrial Crops and Products, 49, 318-325. http://dx.doi.org/10.1016/j.indcrop.2013.05.009

[30] Chaves, M.M., Flexas, J. and Pinheiro, C. (2009) Photosynthesis under Drought and Salt Stress: Regulation Mechanisms from Whole Plant to Cell. Annuals of Botany, 103, 551-560. http://dx.doi.org/10.1093/aob/mcn125

[31] Shah, N.H. and Paulsen, G.M. (2003) Interaction of Drought and High Temperature on Photosynthesis and GrainFilling of Wheat. Plant and Soil, 257, 219-226. http://dx.doi.org/10.1023/A:1026237816578

[32] Suzuki, K., Nagasuga, K. and Okada, M. (2008) The Chilling Injury Induced by High Root Temperature in the Leaves of Rice Seedlings. Plant \& Cell Physiology, 49, 433-442. http://dx.doi.org/10.1093/pcp/pcn020

[33] He, J., Qin, L. and Lee, S.K. (2013) Root-Zone $\mathrm{CO}_{2}$ and Root-Zone Temperature Effects on Photosynthesis and Nitrogen Metabolism of Aeroponically Grown Lettuce (Lactuca sativa L.) in the Tropics. Photosynthetica, 51, 330-340. http://dx.doi.org/10.1007/s11099-013-0030-5

[34] Farooq, M., Wahid, A., Kobayashi, N., Fujita, D. and Basra, S.M.A. (2009) Plant Drought Stress: Effects, Mechanisms and Management. Agronomy for Sustainable Development, 29, 185-212. http://dx.doi.org/10.1051/agro:2008021

[35] Saito, T. and Matsukura, C. (2015) Effect of Salt Stress on the Growth and Fruit Quality of Tomato Plants. In: Abiotic Stress Biology in Horticultural Plants, Springer, 3-16. http://dx.doi.org/10.1007/978-4-431-55251-2_1 